\title{
Foreign Direct Investment Inflows in Pakistan: A Time Series Analysis with Autoregressive Distributive Lag (ARDL) Approach
}

\author{
Sober Mall \\ M.A. Economics (Pb), M.Phil Economics (Superior University), Lahore \\ Kashan-e-Dass, 9610 Ashwood Valley dr, Houston Tx. 77095, United States
}

\begin{abstract}
Estimating a model of foreign direct investment has been one the central elements of FDI policy makers in Pakistan. This paper attempts to model, Determinants of Foreign Direct Investment Inflow in Pakistan: A Time Series Analysis with Auto Regressive Distributive Lag (ARDL) approach using the time series data for the period 1977 to 2010 . However in a specification, FDI is found important with the elasticity of GDP growth rate $10 \%$ level of significance and infrastructure at $1 \%$ level of significance. These factors show do not show better performance in short-run dynamics like only infrastructure is elastic with FDI at $1 \%$ level of significance. Stability tests of the paper do not contain any serious structural change in the model as case of and CUSUM and CUSUMSQ statistics show the critical value lines lying inside the bounds, presenting the model is stable.
\end{abstract}

\section{General Terms}

Your general terms must be any term which can be used for general classification of the submitted material such as Pattern Recognition, Security, Algorithms et. al.

\section{Keywords}

Keywords are your own designated keywords which can be used for easy location of the manuscript using any search engines.

\section{INTRODUCTION}

As a source of foreign investment, foreign direct investment (FDI) with some level of equity plays a glorious and profit oriented role in a sustainable economic growth of the south Asian countries. South Asian countries whether victimizing a poor infrastructure, poor law and order situation, political instability, scarcity of energy supply the blessed nexus of global FDI especially in Bangladesh is credited to cheapest labor cost, tax concessions, tariff reductions or exemptions and other subsidies. During 1980 to 1990 the above stated offerings by the Board of Investors of Bangladesh made the economy of Bangladesh reaped the rising benefits of FDI Anowar Hussain (2012). Hence Bangladesh in the fiscal year 1999 to 2000 was brought to the track of the most liberal investment regime of south Asia Anowar Hussain (2012).

Hence over the last decades the countries being treated with the tablets of liberal economic policies and capital inflows demand the deepen examination of the determinants that influence foreign direct investment particularly in the developing countries like Bangladesh Shafiun Nahin Shimul (2009), Muhammad SALAHUDDIN (2010).
Majority economic literatures lighten the mixed role of FDI in south Asian countries like Bangladesh. Firstly it sources growth enhancing factor of financial market development, inflation rate, infrastructure and GDP growth Kumar, Nagesh, and N.S. Siddharthan(1997), Pardhan (2001), Zaidi (2004), Shafiun Nahin Shimul (2009), Ahmad Ghazali (2010), Muhammad Arshad Khan (2011) and Muhammad Tahir Mahmood (2012). Secondly FDI transfers business know-how and foreign technologies into the host country production function (Romer (1993) and bridges the gap of physical capital, skill acquisition, labor training for human capital formation and more competitive business environment in developing economies Shafiun Nahin Shimul (2009), Rukhsana Kalim (2009). Thirdly FDI initiates to incorporate new inputs such as new commodities that have not been produced by the local firms Shafiun Nahin Shimul (2009). Fourthly as FDI causes an import of substitute firms come in face to face with the local firms which leads to a healthy competition between the firms. Thus the efficiency and productively of the firms are enhanced Shafiun Nahin Shimul (2009). Fifthly for a recipient country is known as the land employment opportunity is also credited to economic blessing of FDI which moves the graph of GDP along with real sense through the factor income of people and indirectly through the multiplier effect Shafiun Nahin Shimul (2009). It however GDP growth with other multiplier effect on the economy could sluggish the saving habits of the people and hence the domestic investment Shafiun Nahin Shimul (2009). Along with above stated crowding in effect of FDI, FDI could have a crowding-out effect in the long-run also when foreign investors become competitors of the local firms by producing the same commodities and drive out the domestic firms from the competition and become a substitute of domestic investment. Shafiun Nahin Shimul (2009), Ahmad Ghazali (2010), Dr. Ch. Abdul Rehman (2011), Muhammad Muazzam Mughal (2011), Haider Mahmood (2012). Some researchers consider that in the presence of pre-existing trade, price, financial, and other distortions FDI causes misallocation of resources which in turn slows the speed of economic growth Brecher and Diaz-Alejandro (1977), Brecher (1983), Boyd and Smith (1999), Carkovic and Levine (2002). So keeping a deliberate perception a positive impact of the relation between FDI and trade on economic growth a faster economic growth along with the open-trade policies are expected by the people so such interrelationship of FDI and trade along with the economic growth is still needed to be critically examined Shafiun Nahin Shimul (2009). 
The present study contributes to supplement the existing literature by empirically examining the behavior of FDI by posing special focus on size of market, gross domestic product growth and public capital in Bangladesh. The study uses time series data from 1972 to 2011 and Autoregressive Distributive Lag Model (ARDL) for empirical estimations. The rest of the paper is organized as follows: section 2 deals with the review of literature, section 3 includes the econometric modeling, data source and the selection of explanatory variables, section 4 presents empirical findings and last section, section 5 concludes the study with some policy recommendations.

\section{REVIEW OF LITERATURE}

The numerous studies are emphasizing upon a considerable research on the FDI determinants. For example: Shafiun Nahin Shimul (2009) applying ARDL approach concludes no cointegration between foreign direct investment and economic growth in Bangladesh during 1973 to 2007. To ensure the above stated result Shafiun Nahin Shimul (2009) took another chance by using Engle-Granger Causality test and inferred FDI and the openness of trade not causing GDP per capita significantly in short-run dynamics as well as in long-run.

\section{DATA SOURCE AND METHODOLOGY:}

\subsection{Data Sources and Variables}

This paper uses annual time series data from 1977 to 2010 analyzing the long-run cointegration among the variables outlined below consisting of Foreign Direct Investment inflow (Current USD) proxied by FDI $\left(F D I_{t}\right)$, Financial Market Development $\left(F M D_{t}\right)$ is proxied by Domestic Credit to Private Sector (\% of GDP), Inflation Rate is proxied by inflation: GDP deflator (Annual \%), Telephone lines has been taken as a proxy of Infrastructure $\left(I S_{t}\right)$, Gross Domestic Product (GDP) Growth Rate (Annual \%) $\left(G D P R_{t}\right)$.

Many of the researchers have already taken these variables in several studies of money demand. For example: Dr. Abdul Rehman (2011). The sample period (1977 to 2010) is constrained by the availability of data which is sourced from World Development Indicator (WDI) and only the variables Foreign Direct Investment inflow $\left(F D I_{t}\right)$ and Infrastructure $\left(I S_{t}\right)$ is taken into logarithm form except Financial Market Development $\left(F M D_{t}\right)$, Inflation Rate $\left(I N F_{t}\right)$ and Gross Domestic Product Growth Rate $\left(G D P R_{t}\right)$.

To examine long-run equilibrium as well as the short-run dynamics of the proposed FDI model we firstly will assure the stationarity properties of the variables selected for estimated in this study. The selected variables if are stationary at level $\mathrm{I}(0)$ the researchers used Ordinary Least Square (OLS) method of regression. If the variables are stationary at first difference $\mathrm{I}(1)$ or at second difference I(2) then most of the research practitioners relied upon Johansen and Juselius maximum likelihood cointegration method for long-run and Error Correction Model for the short-run dynamics. In case of non existence of long-run cointegration among the variables employing Johansen cointegration technique then to examine the short-run dynamics among the variables Granger causal tests mostly is used.

On some doubtful grounds the reliability of Johansen and Juselius cointegration method was pointed out. Such as if some of variables of the proposed model are stationary at level $\mathrm{I}(0)$ and others are at first difference $\mathrm{I}(1)$. So the situation which represents all the variables are not showing the same order of stationarity we have to rely on a cointegration technique named Autoregressive Distributive Lag (ARDL) developed by Pesaran, Shin and Smith (1996). ARDL approach contains both long-run and short-run cointegration among the variables as well as it also examines the short-run dynamics named Error Correction Method. ARDL procedure of cointegration for a long-run equilibrium and short-run dynamics of the model has already been utilized by several research economists. Such as: Dr. Abdul Rehman (2011). All calculations are carried out using Microfit 5.1.

\subsection{Specification of the Function: Foreign Direct Investment}

This study implement the following specification of FDI function can be written as:

$$
F D I_{t}=f\left(F M D_{t}, I N F_{t}, I S_{t}, G D P R_{t}, u_{t}\right)
$$

Where:

$F D I_{t}=$ Foreign Direct Investment inflow (\% of GDP) proxied by FDI $\left(F D I_{t}\right), F M D_{t}=$ Financial Market Development $\left(F M D_{t}\right)$ is proxied by Domestic Credit to Private Sector (\% of GDP), $I N F_{t}=$ Inflation Rate $\left(I N F_{t}\right)$ is proxied by inflation: GDP deflator (Annual \%), IS $S_{t}=$ Infrastructure $\left(I S_{t}\right)$ is proxied by Telephone Lines, $G D P R_{t}=$ Gross Domestic Product (GDP) Growth Rate (Annual \%) $\left(G D P R_{t}\right)$ and $u_{t}=$ Error Term

\subsection{Econometric Model}

Using the logarithmic form for the above discussed variables and redefining the specification into the following multiple semi log linear regression model.

\section{EQUATION NO: (1.1)}

$$
\begin{gathered}
\ln \mathrm{FDI}_{\mathrm{t}}=\beta_{0}+\beta_{1} \mathrm{FMD}_{\mathrm{t}}+\beta_{2} \mathrm{INF}_{\mathrm{t}}+\beta_{3} \operatorname{lnIS}_{\mathrm{t}}+\beta_{4} \mathrm{GDPR}_{\mathrm{t}} \\
+U_{t}
\end{gathered}
$$

Where Foreign Direct Investment $\left(\mathrm{FDI}_{t}\right)$ in natural log form, is a dependent variable whereas Financial Market Development $\left(\mathrm{FMD}_{\mathrm{t}}\right)$, Inflation Rate $\left(\mathrm{INF}_{\mathrm{t}}\right)$, Infrastructure in natural $\log$ form $\left(\operatorname{lnIS}_{t}\right)$ and Gross Domestic Product Growth $\left(\mathrm{GDPR}_{\mathrm{t}}\right)$ are independent variables. On the basis of preliminary analysis only the variable Infrastructure has been presented in (ln) natural logarithmic form. Natural log transformation of the data reduces the variability of variance especially in Infrastructure. Parameters $\beta_{1}, \beta_{2}$, and $\beta_{3}$ are the long-run elasticities of Foreign Direct Investment net inflow with respect to GDPR, FMD and IS respectively. To summarize the prior expectations for the coefficients are as follows: $\beta_{1}>0, \beta_{2}<0, \beta_{3}>0$ and $\beta_{4}>0$.

\subsection{Variable Descriptions and Expected Signs \\ TABLE: (1.0)}

\begin{tabular}{|c|l|c|}
\hline Variable & \multicolumn{1}{|c|}{ Description } & $\begin{array}{c}\text { Expected } \\
\text { Sign }\end{array}$ \\
\hline$F M D_{t}$ & $\begin{array}{l}\text { Financial Market Development } \\
\left(F M D_{t}\right) \text { is proxied by Domestic } \\
\text { Credit to Private Sector (\% of } \\
\text { GDP) } \\
I N F_{t}\end{array}$ & $\begin{array}{l}\text { Inflation Rate is proxied by } \\
\text { inflation: GDP deflator (Annual } \\
\%)\end{array}$ \\
$I S_{t}$ & $\begin{array}{l}\text { Infrastructure (IS }) \text { is proxied by } \\
\text { Telephone mainlines } \\
\text { Gross Domestic Product (GDP) } \\
\text { Growth Rate (Annual \%) } \\
\left(G D P R_{t}\right)\end{array}$ & + \\
$G D P R_{t}$ & + \\
\hline
\end{tabular}


According to the theoretical literature as well as the previous studies the sign of parameter $\beta_{1}$ mostly considered positive as a relation between financial market development and foreign direct investment. It means if financial market development increases this leaves a positive influence in foreign direct investment inflow of an economy and vice versa Wheeler and Mody (1992), Asiedu (2006), Kok and Ersoy (2009), Dr. Ch. Abdul Rehman (2011), Muhammad Muazzam Mughal (2011). The negative sign of coefficient $\beta_{2}$ shows the inflation rate in host country increases will leave an inverse affect on FDI. In case of coefficient $\beta_{2}$ contains a negative relation with foreign direct investment net inflow as negative relation is supported by Wheeler and Mody (1992), Asiedu (2006), Kok and Ersoy (2009), Dr. Ch. Abdul Rehman (2011), Muhammad Muazzam Mughal (2011).

As cardinal variable to the study with a positive expected sign is Infrastructure. Infrastructure as public inputs reduces the cost of business and remains a dominating factor for attracting FDI inflow. Root and Ahmad (1979), Wheeler and Mody (1992), Kinoshta (1998), Kumar, N. (2001), Asiedu (2002), Asiedu (2006), Kok and Ersoy (2009), Khadaroo and Seetanah (2010), Quazi (2005) claims the insignificant influence of infrastructure on FDI inflow. The proxy of "telephone mainlines" (IS) in included in the model to measure the infrastructure as many studies have already utilized this proxy. For example: Sekkat and VeganzonesVaroudakis (2004) and Asiedu (2006), Dr. Ch. Abdul Rehman (2011).

This research paper attempts to examine the model applying auto regressive distributive lag (ARDL) approach to a longrun cointegration for ARDL model deals with a single cointegration equation as well as the variables included in the model to be integrated at level $[\mathrm{I}(0)]$ or at first difference [I(1)] or even both $\mathrm{I}(0)$ and $\mathrm{I}(1)$ integration Pesaran and Shin (1999). Pesaran and Shin (1999) argued the application of ARDL approach to cointegration provides robust results and super consistent estimates of the long-run coefficients in case of both big as well as small samples. The Engle and Granger (1987) test, maximum likelihood based Johansen $(1988,1991)$ and Johansen Juselius (1990) tests are the most widely used methods to investigate the cointegration (long run equilibrium relationship) among the variables Dr. Ch. Abdul Rehman (2011) and require all the variables included in the model must be stationary at first difference $[\mathrm{I}(1)]$ or at second difference [I(2)]. Engle and Granger (1987) test, maximum likelihood based Johansen (1988, 1991) and Johansen Juselius (1990) methods to investigate the cointegration limit the stationarity for most the time series data do not contain the same level stationarity especially at first difference or at second difference as well as the model containing the small samples are estimated with implausible results Dr. Ch. Abdul Rehman (2011). On the other hand Autoregressive distributive lag (ARDL) approach to cointegration avoids the above stated limitations given by Engle and Granger (1987), Johansen (1988, 1991) and Johansen Juselius (1990). Pesaran, Shin and Smith (1996) and Pesaran and Shin (1999) developed this approach whereas Pesaran et al.(2001) developed it further.

Due to various econometric advantages over other methods of cointegration this approach has gained wide acceptance. This approach, contrary to other approaches, does not necessitate all the variables to be integrated of the same order, i.e. I(1).
Considering above advantages of ARDL approaches to cointegration, we specify the following model:

\section{EQUATION NO: (1.2)}

$$
\begin{aligned}
& \Delta\left(\ln F D I_{\mathrm{t}}\right)=\beta_{0} \sum_{\mathrm{i}=1}^{\mathrm{q}} \beta_{1 i} \Delta\left(\ln F D I_{\mathrm{t}-1}\right)+\sum_{\mathrm{i}=0}^{\mathrm{q}} \beta_{2 i} \Delta\left(F M D_{\mathrm{t}-\mathrm{i}}\right) \\
& +\sum_{\mathrm{i}=0}^{\mathrm{q}} \beta_{3 i} \Delta\left(I N F_{\mathrm{t}-\mathrm{i}}\right)+\sum_{\mathrm{i}=0}^{\mathrm{q}} \beta_{4 i} \Delta \ln \left(I S_{\mathrm{t}-\mathrm{i}}\right) \\
& +\sum_{\mathrm{i}=0}^{\mathrm{q}} \beta_{5 i} \Delta\left(G D P R_{\mathrm{t}-\mathrm{i}}\right)+\beta_{6}\left(\ln F D I_{\mathrm{t}-1}\right) \\
& +\beta_{7}\left(F M D_{\mathrm{t}-1}\right)+\beta_{8} \ln \left(I S_{\mathrm{t}-1}\right) \\
& +\beta_{9}\left(G D P R_{\mathrm{t}-1}\right)+v_{t}
\end{aligned}
$$

Where $\Delta$ is the first difference operator, $q$ is optimal lag length, $\beta 1, \beta 2, \beta 3, \beta 4$ and $\beta 5$ represent the short run dynamics of the model whereas $\beta 6, \beta 7, \beta 8$ and $\beta 9$ are the long run elasticities. The long-run elasticity between the FDI inflow (FDI) and its determinants can be examined through the formal procedure of computing the F-statistics. The Fstatistics includes the null hypothesis $\mathrm{H} 0: \beta 6=\beta 7=\beta 8=\beta 9=$ 0 for no cointegration or no long-run relationship between the variables while the alternative $\mathrm{H} 1: \beta 6 \neq 0, \beta 7 \neq 0, \beta 8 \neq 0, \beta 9 \neq$ 0 hypothesis present if there exists a long-run cointegration or long-run relation between the variables. Before running the ARDL model we tested the level of integration of all variables because if any variable is I(2) or above ARDL approach is not applicable. For this we use Augmented Dickey-Fuller test (ADF) and Philips-Perron test (PP). In order to find the long run relationship as given in equation (1.2), we conducted bound test approach using $\mathrm{F}$ - test with two bounds, i.e. lower bound and upper bound. The null hypothesis assumes no cointegration among variables. If the value of F-statistic is greater than upper bound then the null hypothesis is rejected and if it is less than lower and upper bounds then the null hypothesis is accepted and if it falls between the lower bounds the test is inconclusive. After testing for long-run cointegration the selection of lag orders of variables is very important because the appropriate lag selection enables us to identify the true dynamics of the models. To check the performance as well as the true dynamics of the estimated model we use Akaike Information Criteria (AIC) or Schwarz Bayesian Criteria (SBC) for an optimal lag length of variables. This paper also goes through the stability tests, namely, Cumulative Sum (CUSUM) and CUSUM of Squares (CUSUMSQ) of recursive residuals, originally proposed by Brown et al. (1975) are also conducted. An error correction version of equation (1.3) is given as below:

\section{EQUATION NO: (1.3)}

$$
\begin{aligned}
& \Delta \ln \left(F D I_{t}\right)=\beta_{0} \sum_{i=0}^{q_{1}} \beta_{1 i} \Delta \ln \left(F D I_{t-i}\right. \\
&+\sum_{i=0}^{q 2} \beta_{2 i} \Delta\left(F M D_{t-i}\right)+ \\
&+\sum_{i=0}^{q_{3}} \beta_{3 i} \Delta\left(I N F_{t-i}\right) \\
&+\sum_{i=0}^{q_{4}} \beta_{4 i} \Delta \ln \left(I S_{t-i}\right) \\
&+\sum_{i=0}^{q_{5}} \beta_{5 i} \Delta\left(G D P R_{t-i}\right)+\lambda E C_{t-1}+\varepsilon_{t}
\end{aligned}
$$

Where $q_{1}, q_{2}, q_{3}, q_{4}$ and $q_{5}$ represent optimal lag length, $\lambda$ is the speed of adjustment parameter and EC represents the error correction term derived from long run relationship as given in equation (1.3). 


\subsection{Empirical Findings}

Modeling foreign direct investment function applying autoregressive distributive lag (ARDL) approach to cointegration and the testing of the order of integration of the individual series selected in this study. The test of order of integration has been developed several procedures the most popular of them are: Augmented Dickey-Fuller (ADF) test due to Dickey and Fuller $(1979,1981)$, and the Phillip-Perron (PP) due to Phillips and Perron (1988) unit roots test procedure at level and at first difference reported in Table 2.1 showing the analysis of the time series based on ADF and PP unit root tests indicate that the computed values of the time series of variables: Foreign Direct Investment inflow (Current USD) proxied by FDI $\left(F D I_{t}\right)$ has been taken into natural log form, Financial Market Development $\left(F M D_{t}\right)$ is proxied by Domestic Credit to Private Sector (\% of GDP), Inflation: GDP Deflator (Annual \%) has been taken as a proxy of Inflation rate $\left(I N F_{t}\right)$, Infrastructure $\left(I S_{t}\right)$ is proxied by Telephone Lines has been taken into natural $\log$ form and Gross Domestic Product (GDP) Growth Rate (Annual \%) $\left(G D P R_{t}\right)$.

The statistic value of the variables: inflation rate and gross domestic product growth rate at their level $\mathrm{I}(0)$ and first difference $\mathrm{I}(1)$ is greater than the critical values -3.632900 and -3.639407 respectively at $1 \%$ level of significance is shown by $(* * *)$. The said results are based on Augmented DickeyFuller (ADF) unit root test as established by Dickey and Fuller (1979, 1981) and Phillip-Perron (PP) unit root test established by Phillips and Perron (1988).

At level $\mathrm{I}(0)$ and at first difference $\mathrm{I}(1)$ financial market development (FMD) contains it's statistic values -3.638917 and -5.229230 respectively is greater than the critical values 3.632900 of $\mathrm{I}(0)$ and -3.639407 of $\mathrm{I}(1)$ at $1 \%$ level of significance as indicated by $(* * *)$ from applying Augmented Dickey-Fuller (ADF) unit root test. On the other hand PhillipPerron (PP) unit root test shows the statistic value of financial market development (FMD) -2.894099 is significant at 5\% level of significance indicated by $(* *)$ at level $\mathrm{I}(0)$ and $1 \%$ level of significance at first difference I(1).

At level $I(0)$ and at first difference $I(1)$ foreign direct investment inflow (FDI) contains it's statistic values 1.098838 and -5.815790 respectively if compared with the critical values -3.632900 of $\mathrm{I}(0)$ and -3.639407 of $\mathrm{I}(1)$ we will see acceptance of null hypothesis (insignificant result) at level $\mathrm{I}(0)$ and rejection of null hypothesis at $1 \%$ level of significance (significant result) respectively by applying Augmented Dickey-Fuller (ADF) unit root test. On the other hand Phillip-Perron (PP) unit root test shows the statistic value of foreign direct investment (FDI) -1.027036 is insignificant at level $\mathrm{I}(0)$ but At first difference $\mathrm{I}(1)$ the statistic value of FDI -5.794487 significance at $1 \%$ level of significance at first difference I(1).

Another explanatory infrastructure (IS) contains it's statistic values -1.895201 and -1.876959 is detail examined at level $\mathrm{I}(0)$ and at first difference $\mathrm{I}(1)$ respectively and compared with the critical values -3.632900 of $\mathrm{I}(0)$ and -3.639407 of $\mathrm{I}(1)$. Here we see the acceptance of null hypothesis (insignificant result) at level $\mathrm{I}(0)$ and $\mathrm{I}(1)$ based on applying Augmented Dickey-Fuller (ADF) unit root test. On the other hand PhillipPerron (PP) unit root test shows only the statistic value of infrastructure (IS) -3.126815 is significant at $5 \%$ level of significance as indicated by $(* *)$ at first difference $\mathrm{I}(1)$.

The application of Phillip-Perron (PP) and Augmented Dickey-Fuller (ADF) unit root tests contain null hypothesis of these present the presence of a unit root.

Given the unit-root properties of the variables, we proceed to estimate whether there is a long-run cointegration relationship among the variables in equation (1.2) by using Autoregressive distributive lag (ARDL) approach to cointegration. This approach lies in the fact that it can be applied irrespective of whether the variables are $\mathrm{I}(0)$ or $\mathrm{I}(1)$ or $\mathrm{I}(0)$ and $\mathrm{I}(1)$ both in Model (Pesaran and Pesaran 1997). The results of ARDL approach to cointegration have been taken using Microfit (5.0).

Descriptive Statistics:

TABLE: 2.0 (a)

\begin{tabular}{|l|c|c|c|c|c|}
\hline & $F^{2} I_{t}$ & $F^{\prime} D_{t}$ & $I^{N} F_{t}$ & $I_{\boldsymbol{t}}$ & GDPR \\
\hline Observations & 36 & 36 & 36 & 36 & 36 \\
\hline $\begin{array}{l}\text { Standard } \\
\text { Deviation }\end{array}$ & 1433232671 & 2.63 & 5.08 & 1674712 & 2.10 \\
\hline Skewness & 2.451312907 & 0.36 & 1.44 & 0.59 & 0.16 \\
\hline Kurtosis & 5.436388334 & -0.29 & 2.44 & -1.05 & -0.22 \\
\hline Mean & 868213265.5 & 24.86 & 9.87 & 1952951 & 5.11 \\
\hline Maximum & 5590000000 & 29.84 & 24.89 & 5240012 & 10.22 \\
\hline Minimum & 8220530.168 & 19.16 & 2.46 & 208000 & 1.01 \\
\hline
\end{tabular}

Correlation Matrix:

TABLE: $2.0($ b)

\begin{tabular}{|c|c|c|c|c|c|}
\hline & $\boldsymbol{F D I}_{\boldsymbol{t}}$ & $\boldsymbol{F M D}_{\boldsymbol{t}}$ & $\boldsymbol{I N F}_{\boldsymbol{t}}$ & $\boldsymbol{I S}_{\boldsymbol{t}}$ & $\boldsymbol{G D P R}_{\boldsymbol{t}}$ \\
\hline $\boldsymbol{F D I}_{\boldsymbol{t}}$ & $\mathbf{1 . 0 0}$ & & & & \\
\hline $\boldsymbol{F M D}_{\boldsymbol{t}}$ & 0.52 & $\mathbf{1 . 0 0}$ & & & \\
\hline $\boldsymbol{I N F}_{\boldsymbol{t}}$ & 0.15 & -0.40 & $\mathbf{1 . 0 0}$ & & \\
\hline $\boldsymbol{I} \boldsymbol{S}_{\boldsymbol{t}}$ & 0.74 & 0.35 & 0.07 & $\mathbf{1 . 0 0}$ & \\
\hline $\boldsymbol{G D P R}_{\boldsymbol{t}}$ & -0.16 & 0.20 & -0.24 & -0.27 & $\mathbf{1 . 0 0}$ \\
\hline
\end{tabular}

Descriptive statistics and correlation matrix of the variables of our selected model are expressed in Table 2.0 A and 2.0 B respectively.

TABLE: 2.1 Unit Root Test Results

\begin{tabular}{|c|c|c|c|c|}
\hline Variables & $\begin{array}{c}\text { Aug. } \\
\text { Dickey } \\
\text { Fuller } \\
\text { Test } \\
\text { Statistic } \\
\text { (At Level) }\end{array}$ & $\begin{array}{c}\text { Aug. } \\
\text { Dickey } \\
\text { Fuller Test } \\
\text { Statistic } \\
\text { (At 1st } \\
\text { Diff.) }\end{array}$ & $\begin{array}{c}\text { Philips- } \\
\text { Perron } \\
\text { Test } \\
\text { Statistic } \\
\text { (At } \\
\text { Level) }\end{array}$ & $\begin{array}{c}\text { Philips } \\
\text { Perron } \\
\text { Test } \\
\text { Statistic } \\
\text { (At 1st } \\
\text { Diff.) }\end{array}$ \\
\hline $\boldsymbol{I n F D I}_{\boldsymbol{t}}$ & -1.09 & $-5.82 * * *$ & -1.03 & $-5.80 * * *$ \\
\hline $\boldsymbol{F M D}_{\boldsymbol{t}}$ & $-3.64 * * *$ & $-5.23 * * *$ & $-2.90^{*}$ & $-5.34 * * *$ \\
\hline $\boldsymbol{I N F}_{\boldsymbol{t}}$ & $-5.53 * * *$ & $-4.41 * * *$ & $-5.55 * * *$ & $-10.79 * * *$ \\
\hline $\boldsymbol{I n I S}_{\boldsymbol{t}}$ & -1.90 & -1.88 & -1.49 & $-3.13 * *$ \\
\hline $\boldsymbol{G D P R}_{\boldsymbol{t}}$ & $-6.05 * * *$ & $-10.66^{* * *}$ & $-6.10 * * *$ & $-20.91 * * *$ \\
\hline
\end{tabular}


Note: $* * * * *$ and $*$ show significance level at $1 \%$, at $5 \%$ and at $10 \%$ significance levels, respectively. McKinnon (1996) Critical Values: 1\% (-3.632900); 5\% (-2.948404); 10\% (-2.612874) for ADF and PP at I(0). McKinnon (1996) Critical Values: $1 \%$ (-3.639407); 5\% (-2.951125); 10\% (2.614300) for $\mathrm{ADF}$ and $\mathrm{PP}$ at I(1).

Results of the long-run relationship are attached and sensitive to lag-length selected in the model. Table 2.2 presents the computed F-statistic to select optimal lag-length in the model. According to Pesaran et al. (2001), with lag if order 1 the lower and upper bound values at 90 percent significance level are 2.7022 and 3.9116 respectively. Table 2.2 shows that the computed value of F-statistic (3.9217) is greater than the upper bound value of F-statistic which helps us to reject the null hypothesis of no long- run relationship. Therefore, we conclude that there is long-run relationship among the variables. Due to the certain limitations of free downloaded software Microfit 5.0 we are unable to try the second laglength in the model that's why the existence of long-run relationship of the model is ensured by its F-statistic value is little greater than the upper bound at 90 percent significance level.

TABLE: 2.2

F. Statistics for the Existence of Long-run Relation

\begin{tabular}{|c|c|}
\hline Order of Lag & F-Statistic \\
\hline 1 & 3.9217 \\
\hline
\end{tabular}

The lower and upper bound values (2.7022 and 3.9116 at 90 percent) for F-statistic are taken from Microfit 5.0 developed by Bahram Pesaran and M. Hashem Pesaran.

This model was also investigated for any specification error if occurs. For this purpose Ramsey RESET test using the square of the fitted values was incorporated which states if computed F-value is significant then the selected model is considered specifically wrong J. B. Ramsey (1969). In this model the calculated F-statistic lies outside the range of critical values at 5 percent level of significance and therefore, no specification error in our model has been found.

\section{Diagnostic Tests:}

\begin{tabular}{|c|c|c|}
\hline Test Statistics & Description & $\begin{array}{l}\text { Statistic } \\
\text { value } \\
\text { with } \\
\text { [Prob. }]\end{array}$ \\
\hline Serial Correlation & $\begin{array}{l}\text { Lagrange Multiplier Test } \\
\text { of Residual Serial } \\
\text { Correlation }\end{array}$ & $\begin{array}{c}0.3562 \\
{[0.550]}\end{array}$ \\
\hline Functional Form & $\begin{array}{l}\text { Ramsey's RESET Test } \\
\text { using the Square of the } \\
\text { fitted values }\end{array}$ & $\begin{array}{l}3.1885 \\
{[0.074]}\end{array}$ \\
\hline Heteroscedasticity & $\begin{array}{l}\text { Based on the Regression } \\
\text { of Squared Residuals on } \\
\text { Squared fitted values }\end{array}$ & $\begin{array}{c}0.2065 \\
{[0.650]}\end{array}$ \\
\hline
\end{tabular}

To select the optimal lag orders of the variables we have used Schewarz Baysian Criterion (SBC) and concluded the F-static value 3.9217 stays above the upper bounds of the critical values 3.9116 therefore null hypothesis of no long-run cointegration is rejected at 10 per cent level. This result gives an indication for the existence of a long-run relationship between $\operatorname{lnFDI}$, FMD, INF, LnIS and GDPR.

\section{TABLE: 2.4}

Long-Run Coefficient of ARDL $(1,0,0,0,0)$

Dependent Variable $\left(\ln F D I_{t}\right)$

\begin{tabular}{|c|c|c|c|}
\hline Regressor & Coefficient & $\begin{array}{l}\text { Standard } \\
\text { Error }\end{array}$ & t-Ratio \\
\hline Constant & -1.9823 & 2.9965 & -.66153 \\
\hline$F M D_{t}$ & 0.10695 & 0.078320 & 1.3656 \\
\hline$I N F_{t}$ & -0.015621 & 0.047826 & -.32662 \\
\hline $\ln I S_{t}$ & 1.3252 & 0.19751 & $6.7093 * * *$ \\
\hline$G D P R_{t}$ & 0.12652 & 0.10239 & 1.2357 \\
\hline
\end{tabular}

The estimation results provide evidence of the complex dynamics and relatively long effects that seem to exist between FDI and its determinants and fulfill the theoretical expectation about their signs. Table 2.3 reveals that only infrastructure $\left(L n I S_{t}\right)$ could found significant at $99 \%$ percent level of significance and rest of the variables: financial market development $\left(F M D_{t}\right)$, inflation rate $\left(I N F_{t}\right)$ and gross domestic product growth rate $\left(G D P R_{t}\right)$ are found to be insignificant factors of FDI in Pakistan.

The coefficient of financial market development which is positively elastic with FDI in Pakistan shows 5.8035 percent variation in FDI as compared to one percent change in lnPCS. The positive empirical relation of FMD with FDI is carried by the following researchers: Haider Mahmood and A.R. Chaudhary (2012).

Rationale behind negative elasticity of market size is that FDI could have a crowding-out effect when foreign investors invest in Pakistan and become competitors of the local firms by producing the same commodities and drive out the domestic firms from the competition. Hence as a substitute of local entrepreneurs FDI contains a negative causality with annual change in the size of market Haider Mahmood (2012), Ahmad Ghazali (2010), Dr. Ch. Abdul Rehman (2011), Muhammad Muazzam Mughal (2011), Haider Mahmood (2012).

Previous economic theories support positive causality of public capital stock or public investment with economic growth. Public capital stock generates employment process that stimulates economic growth by increasing the domestic output. With an increase in public capital stock with the impact of financial development an economic growth seems to be highly improved. This empirical evidence consistently follows the growth empirics of Mankiw et al. (1992) and Barro and Lee (1994). It is documented that one percent increase investment in public capital yields 5.8035 percent increase in FDI as this argument is supported by Muhammad Shahbaz (2010). 
One percent change in trade openness (TOPEN) could have the same directional change of 12.4729 percent as yield by FDI in long-run provided the Pakistan's security condition is enough. Such relation between FDI and GDPR is documented and supported by several of researchers in the Pakistan like Ahmad Ghazali (2010), Haider Mahmood and A.R. Chaudhary (2012).

The coefficient 0.72578 shows that one percent increase in GDPR leads to over 0.72578 percent yields by FDI in longrun. Such relation between FDI and GDPR is documented and supported by several of researchers in the Pakistan like Ahmad Ghazali (2010), Haider Mahmood and A.R. Chaudhary (2012).

\section{TABLE: 2.5}

Error Correction Representation of the Selected ARDL (1, 0, 0, 0, 0) Model

Dependant Variable $\Delta \ln F D I_{t}$

\begin{tabular}{|l|c|c|c|}
\hline Regressors & Coefficient & $\begin{array}{c}\text { Standard } \\
\text { Errors }\end{array}$ & t-Ratio \\
\hline$\Delta F M D$ & 0.041106 & 0.032944 & 1.2478 \\
\hline$\Delta I N F$ & -0.0060038 & 0.017563 & -0.34185 \\
\hline$\Delta L n I S$ & 0.50931 & 0.16084 & $3.1665^{* * *}$ \\
\hline$\Delta G D P R$ & 0.048625 & 0.035897 & 1.3546 \\
\hline$E C M(-1)$ & -0.38434 & 0.11338 & $-3.3898^{* * *}$ \\
\hline
\end{tabular}

$R^{2}=0.41404$, Adj. $R^{2}=0.30940, \mathrm{~F}(5,28)=3.9569$ [.008], DW $=1.8183$, Hetero. $=0.2065$ [0.650], Ramsey's RESET Test $=3.1885$ [0.074], Note: $* * * * *$ and $*$ show significance level at 1 percent, at 5 percent and at 10 percent significance levels, respectively.

$$
\begin{aligned}
& \text { dLNFDI = LNFDI-LNFDI(-1) } \\
& \text { dFMD = FMD-FMD(-1) } \\
& \text { dINF = INF-INF(-1) } \\
& \text { dLIS = LIS-LIS(-1) } \\
& \text { dGDPR = GDPR-GDPR(-1) }
\end{aligned}
$$

The elasticity of the variable financial development (FMD) does not significantly support the model. The coefficient of financial development which is positively elastic with FDI in Pakistan by 0.041106 percent shows one percent change in market size will cause positively by 0.041106 percent change in FDI.

The diagnostic estimations for the short run dynamics of foreign direct investment are presented in the upper panel of Table 2.5 shows gross domestic product growth $\left(\triangle G D P R_{t}\right)$ elasticity is 0.048625 which is not significant as reflected by a t-statistics (t-ratio) of 1.3546 . The coefficient 0.048625 shows that one percent increase in GDPR leads to increase FDI by 0.048625 percent in short-run period of time.

ECM (-1) presents the convergence of the model towards equilibrium by its negative sign and the value 0.38434 shows FDI adjusts to restore 38.4 percent of a disequilibrium from the previous year to the current year and low speed of adjustment indicates could be the element of political instability, energy crises and currency devaluation.

A microscopic examination of the table indicates that a low coefficient of determination. This can be observed from the value of R-squared 41.4 percent and the adjusted R-squared 30.9 percent. Although there are several findings contain Rsquare less than $50 \%$ in short run dynamics. For example: the value of $\mathrm{R}^{2}$ given in the table 2.4 shows only $58 \%$ variation in error correction model (short-run relation equilibrium) is providing better performance of the model in short-run

Plot of Cumulative Sum of Recursive Residuals

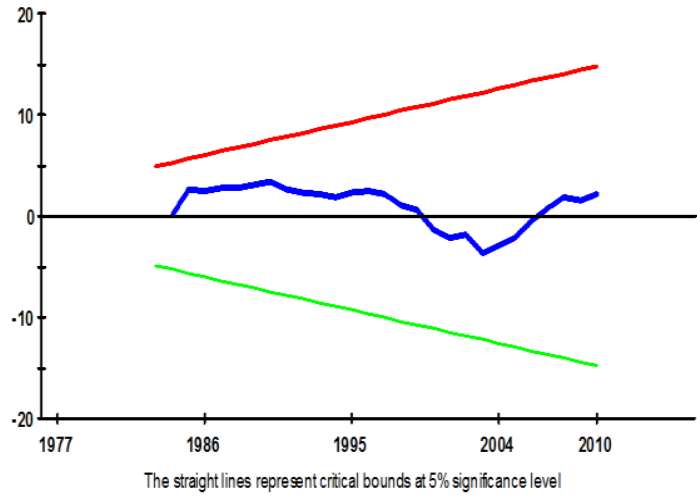

This research paper purposes an estimation of a dynamic demand for money function in Pakistan that could hold a key position for an optimal policy analysis we finally examine the stable:

Model is reported in the table 2.5 apply the level of stability tests CUSUM and CUSUMSQ proposed by Brawn et al. (1975). "It is now becoming standard practice to incorporate short-run dynamics in testing for the stability of the long-run parameters of the money demand equation" Olugbenga A. Onafowora (International Business \& Economics Research Journal: Volume 3, Number 8). Once variables are confirmed for a long-run cointegration then the stability of foreign direct investment function can be tested. If graphical plot of CUSUM and CUSUMSQ stays within 5\% significance level, then our proposed FDI function is said to be a stable function. So incorporating the stability tests using both the CUSUM and CUSUMSQ this paper contain no structural change in the model.

\section{Plot of Cumulative Sum of Squa res of Recursive Residuals}

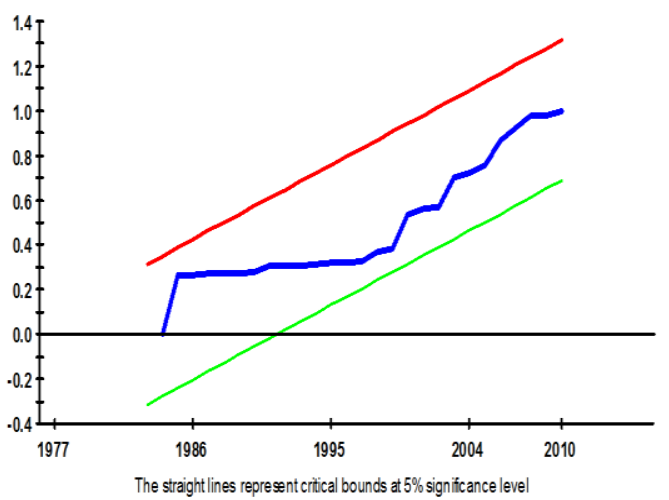


Model is reported in the table 2.5 apply the level of stability tests CUSUM and CUSUMSQ proposed by Brawn et al. (1975). "It is now becoming standard practice to incorporate short-run dynamics in testing for the stability of the long-run parameters of the money demand equation" Olugbenga A. Onafowora (International Business \& Economics Research Journal: Volume 3, Number 8). Once variables are confirmed for a long-run cointegration then the stability of foreign direct investment function can be tested. If graphical plot of CUSUM and CUSUMSQ stays within 5\% significance level, then our proposed FDI function is said to be a stable function. So incorporating the stability tests using both the CUSUM and CUSUMSQ this paper contain no structural change in the model.

\section{POLICY IMPLICATIONS OF THE FINDINGS}

The evidence of an important implications derived from the above findings suggest gross domestic product growth, financial market development, size of market, public capital stock and the openness of trade are the important determinants of FDI in Pakistan. The finding of the study may contribute in the following areas: firstly the developing countries like Pakistan are unable to reap the optimal benefits of FDI due to the political instability. The optimal fruits of FDI require firm political stability under democracy. Secondly the government should reshape its image in trust worthy frame to restore the size of local firms (size of market). For this very purpose government should deal with the promises which she has made with the investors and should complete all the energy related projects on primarily bases. Thirdly we second the policy implication by Muhammad Arshad Khan (2007) who argues that having a better ability to absorb the positive impact of FDI and promoting economic performance a well developed financial sector can represent a source of comparative advantage for Pakistan. Fourthly the study strongly supports the effective concentration of the international donor agencies like UNO, ADB and IMF and the friend countries of Pakistan on the economic infrastructure reconstruction. It will result in twofold benefit, first is rehabilitation and second is maintaining and uplifting of FDI inflow 2) the same concentration is required by the policy makers to ensure the significant factors while making policies in respect of FDI. Fifthly the government should redefine the priorities in favor of FDI that could affect foreign capital more. Iqbal Mahmood (2011) argues for government capabilities must be taken into account while it designs its FDI favorable policies. Sixthly economies like Pakistan should rely upon their own resources rather they finance their economies from other external sources to attain self sufficiency and economic growth.

\section{CONCLUSION}

In this paper we develop an econometric model of foreign direct investment, with application of recent econometric methodology of Auto Regressive Distributed Lag (ARDL) to cointegration analysis of Pesaran and Shin (1998) and Pesaran et al. (2001). The results show that gross domestic product growth rate, financial market development, public capital stock and trade openness have positive relation with FDI while the size of market negatively associated with FDI in short run as well as long run. An annual time series data set over the period 1970 to 2010 is utilized. Recent data techniques are applied to diagnose and check the time series properties of data; later estimation was carried out where Short run and long run elasticities are estimated.
Our results state that capital stock and foreign direct investment are important factors which affect significantly and positively. Our findings are consistent with the findings of Haider Mahmood (2012), Ahmad Ghazali (2010), Dr. Ch. Abdul Rehman (2011), Muhammad Muazzam Mughal (2011), Haider Mahmood (2012).

The stability of our proposed FDI model has been examined to assure the short run dynamics for long run consistency of parameters applying CUSUM test based on cumulative sum of recursive residuals and CUSUMSQ test is based on squared recursive residuals as initially proposed by Brawn et al (1975). The CUSUM test is plotted against the break points. The estimated coefficients are said to be stable in case if the plot of CUSUMSQ statistic stays within 5\% level of significance.

\section{REFERENCES}

[1] Harrod, R. F. (1939). An Essay in Dynamic Theory, The Economic Journal, 49, 14-33.

[2] Domar, E. D. (1946). Capital Expansion, Rate of Growth, and Employment, Econometrica, 14, 137-147.

[3] Bandera, V. N., \& White, J. T. (1968). U.S. Direct Investments and Domestic Markets in Europe, Economia Internazionale. 21, 117-133.

[4] J. B. Ramsey (1969) Tests for Specification Errors in Classical Linear Least Squares Regression Analysis. Journal of the Royal Statistics Society, series B, vol. 31 , 1969, pp. 350-371.

[5] Schmitz, A., \&. Bieri (1972). EEC Tariffs and U. S. Direct Investment, European Economic Re-view. 3: 259 -270 .

[6] McKinnon, R.I., (1973). Money and Capital in Economic Development, Brookings Institution, Washington, DC.

[7] Bowers, W. and Pierce, G.(1975), The illusion of deterrence in Isaac Ehrlich's work on the deterrent effect of capital punishment, Yale Law Journal, 85, 187-208.

[8] Brecher, R. and C. Diaz-Alejandro, (1977), Tariffs, Foreign Capital and Immiserizing Growth, Journal of, International Economics, 7, 317-322.

[9] Ehrlich, I., (1977), The Deterrent Effects of Capital Punishment Reply, American Economic Review, 67, 45258.

[10] Kojima, K. (1978). Direct Foreign Investment: A Japanese Model of Multinational Business Operations. London: Croom Helm.

[11] Root, F.R., and Ahmed, A. (1979). Empirical Determinants of Manufacturing Direct Foreign Investment in Developing Countries, Economics Development and Cultural Change, 27, 751-767.

[12] Dickey D.A. and Fuller W.A (1979), Distributions of the estimators for autoregressive time series with a unit root, Journal of American Statistical Association, 74: 427431.

[13] Dickey, D.A and W.A. Fuller (1981), Likelihood ratio statistics for autoregressive time series with a unit root. Econometrica, 49, pp. 1057-1072.

[14] Brecher, R. (1983), Second-Best Policy for International Trade and Investment, Journal of International Economics, 14, 313-320. 
[15] Engle, R., and C. Granger (1987) Cointegration and Error Correction: Representation, Estimation, and Testing. Econometrica 55, 251-276.

[16] Phillips, P.C.B. and P. Perron (1988) Testing for a Unit Root in Time Series Regression, Biometrika, 75, 335346.

[17] Johansen, S. (1988) Statistical Analysis of Cointegration Vectors, Journal of Economic Dynamics and Control 12.

[18] Johansen, S., \& Juselius, K. (1990). Maximum Likelihood Estimation and Inference on Co-Integration with Application for the Demand for Money. Oxford Bulletin of Economics and Statistics, 52, 169-210.

[19] Romer, P. (1990). Endogenous Technological Change, Journal of Political Economy, 98(5), S71-102.

[20] Wang, J. Y. (1990). Growth, Technology Transfer, and Long-Run Theory of International Capital Movements, Journal of International Economics, 29(3-4), 255-271.

[21] Johansen, S. (1991) A Statistical Analysis of Cointegration for I(2) Variables, University of Copenhagen.

[22] Grossman, G. M. \& Helpman, E. (1991). Innovation and Growth in the Global Economy. Cambridge MA: The MIT Press.

[23] Wheeler, D., \& Mody A. (1992). International investment location decisions: the case of U.S. firms, Journal of International Economics, 33, 57-76.

[24] Mankiw, G., Romer D. and Weil, D., (1992). A Contribution to the Empirics of Economic Growth, Quarterly Journal of Economics, 152, 407-437.

[25] Boyd, J.H. and Smith, B.D (1992). Intermediation and the Equilibrium Allocation of Investment Capital: Implications for Economic Development, Journal of Monetary Economics, 30, 409-432.

[26] Ruffin, R. J. (1993). The Role of Foreign Investment in the Economic Growth of the Asian and Pacific Region. Asian Development Review, 11(1), 1-24.

[27] Atje, Raymond and Boyan and Jovanovic (1993). Stock Markets and Development, European Economic Review, $37(2 / 3), 632-40$

[28] Bhagwati, J.N. (1994), Free trade: Old and new challenges, Economic Journal, 104, 231-246.

[29] Barro, R.J. and Lee, J-W. (1994). Source of Economic Growth, Carnegie-Rochester Conf Ser Public Policy 40, 1-46.

[30] Johansen, S. (1995) Likelihood Based Inference in Cointegrated Vector Auto-regressive Models, Oxford: Oxford University Press.

[31] Demirgue-Kunt, A. and Levine R. (1996a), Stock Market Corporate Finance and Economic Growth: An Overview, The World Bank Review, 10(2): 223-239.

[32] Demirgue-Kunt, A. and R. Levine (1996b), Stock Market Development and Financial Intermediaries: Stylized Facts, World Economic Review, 10(2): 291-321

[33] Pesaran, M. H., Shin, Y., \& Smith, R. J. (1996). Testing for the 'Existence of a long-mn relationship, Faculty of Economics, University of Cambridge, Cambridge Working Papers in Economics 9622.
[34] MacKinnon, James G. (1996) Numerical Distribution Functions for Unit Root and Cointegration Tests, Journal of Applied Econometrics, 11, 601-618.

[35] Kumar, Nagesh, and N.S. Siddharthan(1997). Technology, Market Structure and Internationalization Issues and Policies for Developing Countries, Routledge and UN Press, London and New York.

[36] Pesaran, H., \& Pesaran, B. (1997). Microfit 4.0 interactive econometric analysis. Oxford: Oxford University Press.

[37] Walz, U. (1997). Innovation, Foreign Direct Investment and Growth. Economica, 64, 63-79.

[38] Bannerjee, A., J. Dolado, and Mestre, R. (1998), Error Correction Mechanism Tests for Co-integration In Single Equation Framework, Journal of Time Series Analysis, 19, pp. 267-83

[39] Kinoshta, Y. (1998). Micro-determinants of Japanese Foreign Direct Investment in Asia, Eastern Economic Association and Japan Economic Seminar at Columbia University.

[40] Khan, H. A., \& Kim, Y. (1999), EDRC (Report Series No. 66)

[41] Markusen, J. \& Venables, A. (1999). Foreign Direct Investment as a Catalyst for Industrial Development, European Economic Review, 43(2), 335-56.

[42] Morrisset, P. (2000). Foreign Direct Investment to Africa: Policies also Matter, Transnational Corporation 9(2), 107-125.

[43] Akhar, H. M. (2000). The determinants of FDI in Pakistan: An Econometrics Analysis, The Lahore Journal of Economics, 5:1.

[44] Pistoresi, B. (2000). Investimenti diretti esteri e fattori di localizzazione: L'America Latina e il Sud Est asiatico, Rivista di Politica Economica, 90, 27-44.

[45] Kumar, N. (2001). Infrastructure Availability, Foreign Direct Investment Inflows and Their Export-orientation: A Cross-Country Exploration. Research and Information System for Developing Countries, New Delhi, November 2001.

[46] Pesaran, H. M., Shin, Y., \& Smith, R. J. (2001). Bounds Testing Approaches to the Analysis of Long-Run Relationships, Joumal of Applied Econometrics, 16, 289 326.

[47] Pradhan, \& Prakash, J. (2001). Foreign Direct Investment and Economic Growth: The Case of Developing Countries, Unpublished M.Phil Dissertation submitted to Jawarhlal Nehru University, New Delhi

[48] Seid, S. H. (2002). Global Regulations of Foreign Direct Investment. 131 Main Street Burington, VT 05401-5600 USA, Ashgate Publishing Company

[49] Carkovic, Maria, and Ross Levine (2002), Does Foreign Direct Investment Accelerate Economic Growth? Department of Finance Working paper, University of Minnesota.

[50] Claessens, S., Daniela KL., and Schmukler, S.L. (200203), 'The future of Stock Exchanges in Emerging Markets- Evolution and Prospects', Brookings-Wharton 
Papers on Financial Services 2002, The Brookings Institution, Washington, D.C., 167-212.

[51] Claessens, Stijn, Daniela K., and Schmukler, S., (2002), 'FDI and Stock Market Development: Complements or Substitutes?', Conference Paper, Washington DC October 3-4, 2002

[52] Asiedu, E. (2002). On the determinants of foreign direct investment to developing countries: is Africa different? World Development, 30(1), 107-118

[53] Prasad, E., K. Rogoff, S. Wie and A. Kose (2003) Effects of Financial Globalization on Developing Countries: Some Empirical Evidence, IMF Occasional Paper No. 220, (Washington International Monetary Fund).

[54] Sekkat and Veganzones-Varoudakis (2004). Trade and Foreign Exchange Liberalization, Investment Climate and FDI in the MENA Countries. Working Papers $D U L B E A$, University of Oxford: Oxford.

[55] Aqeel, A., \& Nishat M. (2004). The determinants of foreign direct investment in Pakistan. The Pakistan Development Review, 43(4) II, 651-664.

[56] Cypher, J. M. \& Dietz, J. L. (2004). The Process of Economic Development (2nd ed.), London and New York: Routledge.

[57] Zaidi, H. H. (2004). "Snags in Inflow of FDI", DOWNBusiness 09 August, 2004, Available at http://www.down.com/2004/08/09/ebr7.htm

[58] State Bank of Pakistan (2005). Handbook of Pakistan Economy 2005, available at http://www.sbp.pk.org/departments/stats/PakEconomy_ Handbook/Index.htm

[59] Anjum Aqeel (2005). The Determinants of Foreign Direct Investment in Pakistan, Submitted for $20^{\text {th }}$ Annual PSDE conference to be held on 10-12 January 2005, Islamabad.

[60] Fritz Foley C., Mihir A. Desai and James R. Hines Jr. (2005), Foreign Direct Investment and the Domestic Capital Stock, American Economic Review Papers and Proceedings 92, no. 2 (May 2005): 33-38

[61] Quazi, R. (2005), Economic Freedom and Foreign Direct Investment in East Asia, College of Business, Prairi View A\&M University, Prairi View Texas 77446. USA International Academy of Business and Public Administration Disciplines (IABPAD) Meetings.

[62] Mlambo, K. (2006). Reviving Foreign Direct Investments in Southern Africa: Constraints and Policies, African Development Review, 17(3), 552-579.

[63] Asiedu, E. (2006). Foreign direct investment in Africa: the role of government policy, institutions and political instability. World Economy, 29(1), 63-77.

[64] Sahoo, P. (2006). Foreign Direct Investment in South Asia: Policy, Trends, Impact and Determinants, $A D B$ Institute Discussion Paper No. 56.

[65] Khan, M. A. (2007). Foreign Direct Investment and Economic Growth: The Role of Domestic Financial Sector. Pakistan Institute of Development Economics (PIDE) Working Paper 18.

[66] Kyereboah-Coleman A, Tettey KA (2008). Effects of Eschange Rate Volitility on Foreign Direct Investment in
Sub-Saharan Africa: The case of Ghana, J. Risk Finan., 09(01): 52-70.

[67] Russ KN (2008). Eschange Rate Volitility and First Time Entry By Multinational Firms. National Bureau of Economic Research Working Paper Series, wp/13659.

[68] Zhang, H. K. (2008). What attracts Foreign Multinational Corporations to China?, Contemporary Economic Policy, 19(3), 336-346.

[69] Chowdhry A, Wheeler M (2008), Does Real Exchange Rate Volitility Affect Foreign Direct Investment? Evidence from Four Developed Economies. Int. Trade J., 22(02).

[70] Chousa, Juan P., Krishna, C. and Tamazian, A. (2008). Does Growth \& Quality of Capital Markets Drive Foreign Capital? William Davidson Institute Working paper Series, University of Michigan, Stephen M. Ross Business School. 911 No.

[71] Kok, R., \& Ersoy, A. B. (2009). Analyses of FDI determinants in developing countries. International Journal of Social Economics, 36(1/2), 105 - 123.

[72] Nuzhat Falki (2009). Impact of Foreign Direct Investment on Economic Growth of Pakistan, International Review of Business Research Papers, Vol. 5, No. 5, September 2009, pp. 110-120.

[73] State Bank of Pakistan (2005), Annual Reports 2008-09: The State of Pakistan's Economy, Volume-I, State Bank of Pakistan: Karachi.

[74] de la Torre, Augusto de la, Gozzi, Juan Carlos, and Schmukler, Sergio L. (2007), Stock Market Development under Globalization: Whither the Gains from Reforms? Policy Research working paper No. wps4184, World Bank.

[75] Desai, Mihir A, Foley, C. Fritz, James R. and Jr. Hines (2007), Foreign Direct Investment and the Domestic Economic Activity, NBER Working paper No 11717.

[76] Ogunleye (2009). Exchange Rate Volatility and Foreign Direct Investment in Sub Saharan Africa: Evidence from Nigeria and South Africa, PhD Dissertation Extract: African Center for Economic Transformation.

[77] Rukhsana Kalim (2009). Impact of Foreign Direct Investment on Stock Market Development: The Case of Pakistan, $9^{\text {th }}$ Global Conference of Business and Economics, Cambridge University, UK, ISBN: 978-09742114-2-7.

[78] Adam, Anokye, M. and Tweneboah, George (2009). Foreign Direct Investment and Stock Market Development: Ghana's Evidence, International Research Journal of Finance and Economics, 26. pp. 179-185.

[79] Chege E (2009). Exchange Rate Volitility Effects on Inward Foreign Direct Investments in Emerging Markets, Maastricht University Masters of Science in International Business.

[80] Shafiun Nahin Shimul (2009). An Examination of the FDI and Growth Nexus in Bangladesh: Engle Granger and Bounds Testing Cointegration Approach, BRAC University Journal, vol. VI, no. 1, 2009, pp. 69-76. 
[81] Khadaroo, A. J., \& Seetanah, B. (2010). Transport infrastructure and foreign direct investment. Journal of International Development, 22, 103-123.

[82] Muhammad SALAHUDDIN (2010). A Note on Causal Relationship between FDI and Savings in Bangladesh, Theoretical and Allied Economics, Volume XVII (2010), No. 11(552), pp. 53-62.

[83] Ahmad Ghazali (2010). Analysing the relationship between Foreign Direct Investment, Domestic Investment and Economic Growth for Pakistan, International Research Journal of Finance and Economics, ISSN 1450-2887, Issue 47 (2010).

[84] Muhammad Shahbaz (2010). Foreign Capital Inflow Growth Nexus and Role of Domestic Financial Sector: An ARDL Cointegration Approach for Pakistan, M.S. and M.M.R./ Journal Economic Research, 15 (2010), 202-231.

[85] Muhammad Shahbaz (2010). Foreign Direct Investment and Economic Growth Nexus and Role of Domestic Financial development in Portugal.

[86] Hafeez-ur-Rehman (2010). Impact of Foreign Direct Investment Inflow on Equilibrium Real Exchange Rate of Pakistan, A Research Journal of South Asian Studies, Vol. No. 25, No. 1, January-June 2010, pp. 125-141.

[87] G. Jayachandran (2010). A causal relationship between Trade, Foreign Direct Investment and Economic Growth in India, International Research Journal of Finance and Economics, ISSN 1450-2887 Issue 42 (2010).

[88] Nazima Elahi (2011). Exchange Rate Volatility and Foreign Direct Investment (FDI) Behavior in Pakistan: A
Time Series Analysis with Autoregressive Distributive Lag (ARDL) Application, Africal Journal of Business Management Vol. 5(29), pp. 11656-11661, 23 November, 2011.

[89] Nazima Elahi (2011). Testing the Joint Impact of Foreign Aid and Foreign Direct Investment on Overtime Economic Growth of Pakistan, $2^{\text {nd }}$ International Conference of Business and Economic Research $\left(2^{\text {nd }}\right.$ ICBER 2011), Proceeding.

[90] Muhammad Muazzam Mugal (2011). Does market size affect FDI? The case of Pakistan, Interdisciplinary Journal Of Contemporary Research In Business, Vol. 2, No. 9, Listed In ULRICH'S.

[91] Muhammad Arshad Khan (2011). Foreign Direct Investment in Pakistan: The Role of International Political Relations, University of Oxford, Department of International Development, ISSN 2045-5119.

[92] Dr. Ch. Abdul Rehman (2011). The impact of infrastructure on foreign direct investment: the case of Pakistan. International Journal of Business and Management, Vol. 06, No. 5; May 2011.

[93] Muhammad Tahir Mahmood (2012). The Impact of FDI on Economic Development of Pakistan. Journal Social and Development Sciences, Vol.3, No. 2, pp. 59-68, Feb 2012, (ISSN 2221-1152).

[94] Haider Mahmood and A.R. Chaudhary (2012). Foreign Direct Investment-Domestic Investment Nexus in Pakistan, Middle-East Journals of Scientific Research 11 (11): 1500-1507, 2012, ISSN 1990-923. 